\title{
Evaluation of clinical and biological parameters concerning the implications of smoking on the periodontium
}

\author{
Evaluarea unor parametri clinico-biologici privind implicaţiile fumatului asupra \\ parodonţiului marginal
}

\author{
Dorina-Cerasella Şincar, Mioara Decusară, Gabriela Popa, Gina-Păunița Grecu, \\ Gabriel-Valeriu Popa \\ Departamentul de Medicină dentară, Facultatea de Medicină şi Farmacie, \\ Universitatea „Dunărea de Jos“, Galaţi, România
}

\begin{abstract}
Introduction. Numerous studies have revealed the connection between various oral disease and smoking, and there is a concern to raise public awareness of the harmful effects of smoking. The mechanisms which smoking acts in periodontal disease are not fully elucidated. It has been shown that there is a qualitative change in the microorganisms involved in the production of periodontal disease in smokers.

Material and method. There were 40 patients, 18 female and 22 male subjects aged 18-28 who underwent examination and treatment. The evaluation was based on a general data collection questionnaire, combined with OPG radiographs and supplemented by a rigorous clinical examination. As additional investigations, determination of the plasma level of reactive C-reactive protein (CRP) was performed. For the diagnosis of pathogens related to the occurrence and progression of periodontitis, the PET test (Periodontitis/Periimplantitis Patogen Test) was used.

Results and discussions. The higher the consumption of tobacco, it was found that the periodontal disease was more severe. Consumption of up to 10 cigarettes per day determine in marginal periodontium changes, but quitting smoking makes periodontal disease more responsive to treatment than large smokers who, even if they do not, have a modified local reactivity.

Conclusions. The results of the study confirm that smoking has a masking effect of inflammatory phenomena at the periodontium level by reducing the periodontal haemorrhagic response. Smoking affects the subgingival bacterial profile, being responsible for decreasing the number of beneficial bacteria and increasing parodonto-pathogenic bacteria.
\end{abstract}

Keywords: periodontal disease, smoking

\section{REZUMAT}

Introducere. Numeroase studii au relevat legătura dintre diverse afecţiuni ale cavităţii orale şi fumat, existând în acest sens o preocupare pentru conştientizarea opiniei publice asupra efectelor nocive ale fumatului. Mecanismele prin care fumatul acţionează în boala parodontală nu sunt deplin elucidate. S-a demonstrat că există o modificare calitativă a microorganismelor implicate în producerea bolii parodontale la fumatori.

Material şi metodă. Au fost urmăriţi 40 de pacienţi, 18 de sex feminin şi 22 de sex masculin, cu vârste cuprinse între 18 şi 28 de ani, care au solicitat examen şi tratament de specialitate. Evaluarea s-a făcut pe baza unui chestionar de culegere de date generale, coroborată cu radiografii OPG şi completată de un examen clinic riguros. Ca investigaţii suplimentare s-au efectuat determinarea nivelului plasmatic al proteinei $\mathrm{C}$ reactive (CRP). Pentru diagnosticarea agentilor patogeni, care au legătură cu apariţia şi evoluţia parodontitei s-a utilizat testul PET (Parodontita/Periimplantita Patogen Test).

Rezultate şi discuţii. Cu cât consumul de tutun a fost mai mare s-a constatat că formele de îmbolnăvire parodontală au fost mai severe. Un consum de până la 10 ţigări/zi determină modificări la nivelul parodonţiului marginal, dar renunţarea la fumat face ca afecţiunile parodontale să fie mai responsive la tratament comparativ cu marii fumători, care, chiar dacă renunţă la acest obicei, prezintă o reactivitate locală modificată.

Concluzii. Rezultatele studiului realizat confirmă faptul că fumatul are un efect de mascare a fenomenelor inflamatorii de la nivelul parodonţiului prin reducerea răspunsului hemoragic parodontal. Fumatul afectează profilul bacterian subgingival, fiind responsabil pentru scăderea numărului bacteriilor benefice şi creşterea bacteriilor parodontopatogene.

Cuvinte cheie: boală parodontală, fumat 


\section{INTRODUCERE}

În ultimii ani există o preocupare din ce în ce mai mare privind efectele nocive ale fumatului, în condiţiile unei creşteri a frecvenţei fumatorilor in cadrul populaţiei active. Numeroase studii au relevat legătura dintre diverse afecţiuni ale cavităţii orale şi fumat, existând în acest sens o preocupare pentru conştientizarea opiniei publice asupra efectelor nocive ale fumatului. Mecanismele prin care fumatul acţionează în boala parodontală nu sunt deplin elucidate. S-a demonstrat că exista o modificare calitativă a microorganismelor implicate în producerea bolii parodontale la fumători. De asemenea fumatul produce şi o diminuare a răspunsului imun local, prin scăderea numărului şi afectarea funcţiilor neutrofilelor (celule de apărare) şi o diminuare a producerii de anticorpi. Există un raţionament de ordin biologic pentru efectele negative ale fumatului de ţigări asupra ţesutului parodontal. În primul rând, fumatul are un efect asupra imunităţii fumătorului, afectând interacţiunile microorganismului cu gazda. Motilitatea periferică a leucocitelor polimorfonucleare din sânge, chemotaxis şi fagocitoză sunt defectuoase, prin urmare compromit prima linie de apărare împotriva bacteriilor subgingivale. În plus, fumătorii produc mai puţini anticorpi, în special IgG2, subclasa cea mai importantă la bacteria parodontală şi un nivel scăzut de celule T imunoreglatorii. Rezultatul net este că organismele ce colonizează spaţiile parodontale la fumătorii de ţigară nu prezintă mecanisme imune specifice şi nonspecifice de curăţare, permiţându-le să se stabilească subgingival.

Scopul studiului a fost evaluarea efectul consumului de tutun asupra stării de sănătate parodontală şi a microbiotei parodontale, precum şi de a evalua corelativ nivelul sanguin al proteinei $\mathrm{C}$ reactive la fumătorii din lot.

\section{MATERIAL ŞI METODĂ}

Studiul s-a efectuat în perioada 01.11.2017 31.05.2018 într-un cabinet de medicină dentară din Centrul Stomatologic Ţiglina I din Galaţi, unde au fost urmăriţi 40 de pacienţi, 18 de sex feminin şi 22 de sex masculin, cu vârste cuprinse între 18-28 de ani, care au solicitat examen şi tratament de specialitate. Evaluarea s-a făcut pe baza unui chestionar de culegere de date generale, coroborată cu radiografii OPG şi completată de un examen clinic riguros. Ca investigaţii suplimentare s-a efectuat determinarea nivelului plasmatic al proteinei $\mathrm{C}$ reactive (CRP). Au fost prelevate probe de placă subgingivală ce au fost colectate în acelaşi timp al zilei (după-amiază, aproximativ 5-7 ore după periaj). S-au recoltat probe de la fiecare pacient inserându-se conuri de hârtie sterile (dimensiunea 30 , două conuri de hârtie per situs) în sulcusul gingival sau în punga parodontală, timp de 10 secunde, după izolarea şi îndepărtarea plăcii supragingivale. Probele au fost plasate în tuburi de microcentrifugă de 1,5 $\mathrm{ml}$ cu $300 \mu \mathrm{l}$ tampon fosfat înghețat la $-80^{\circ} \mathrm{C}$ până la o analiză ulterioară. La toţi pacienţii s-a recoltat sângele periferic, iar plasma a fost ob̧̧inută după centrifugare la $1.500 \mathrm{x}$ g timp de $10 \mathrm{~min}$ şi depozitată la $-4{ }^{\circ} \mathrm{C}$ în vederea analizei valorilor proteinei C reactive (Eckersall şi colab., 2004). Pentru diagnosticarea agenţilor patogeni, care au legătură cu apariţia şi evoluţia parodontitei s-a utilizat testul PET (Parodontita/Periimplantita Patogen Test). Au fost testate calitativ si cantitativ urmatoarele microorganisme: Aggregatibacter actinomycetemcomitans, Porphyromonas gingivalis, Treponema denticola, Tannerella forsythia, Prevotella intermedia, Fusobacterium nucleatum, Peprostreptococcus, Capnocytophaga gingivalis, Eubacterium nodatum. Studiul t-test a fost realizat folosind pachetul software SPSS (versiunea 7.0). Pacienţii care au acceptat să participe la studiu au semnat un consimțământ informat în scris.În lotul de pacienţi au fost incluşi 10 de pacienţi fumători, sănătoşi, fără semne de de afectare parodontală, 13 pacienţi cu gingivită cronică şi 17 dintre pacienţi au prezentat parodontită marginală.

\section{REZULTATE ŞI DISCUȚII}

Din punct de vedere al frecvenţei cazurilor întâlnite, s-a constatat că $61 \%$ dintre cazurile de parodontită au fost înregistrate la sexul masculin, în timp ce la sexul feminin au predominat cazurile de gingivită $-57 \%$. Tabagismul cronic predomină la bărbaţi, dar este în creştere accelerată la femei şi la tineri, fiind perceput ca mijloc de emancipare. Astfel am urmărit dacă se poate face o corelaţie între consumul de tutun şi nivelul de educaţie. Din datele obţinute s-a constatat că aproximativ $2 / 3$ dintre fu- 
mători aveau studii superioare, în timp ce aproximativ $1 / 3$ dintre fumători prezentau studii medii, majoritatea fumătorilor pretextând o motivaţie de ordin psihologic sau de stres psiho-emoţional. $\mathrm{Cu}$ cât consumul de tutun a fost mai mare s-a constatat că formele de îmbolnăvire parodontală au fost mai severe. Un consum de până la 10 ţigări/zi determină modificări la nivelul parodonţiului marginal, dar renunţarea la fumat face ca afecţiunile parodontale să fie mai responsive la tratament comparativ cu marii fumători, care chiar daca renunță la acest obicei, prezintă o reactivitate locală modificată. Din punct de vedere al indicilor parodontali, au existat diferenţe între adâncimea de sondare PPD (Fig. 1) şi pierderea de ataşament CAL (Fig. 2), între cele trei sub grupuri de studiu (pacienţi sănătoşi, cu gingivită şi cu parodontită cronică).

PDD (edie \pm SD $\mathrm{mm}$ )

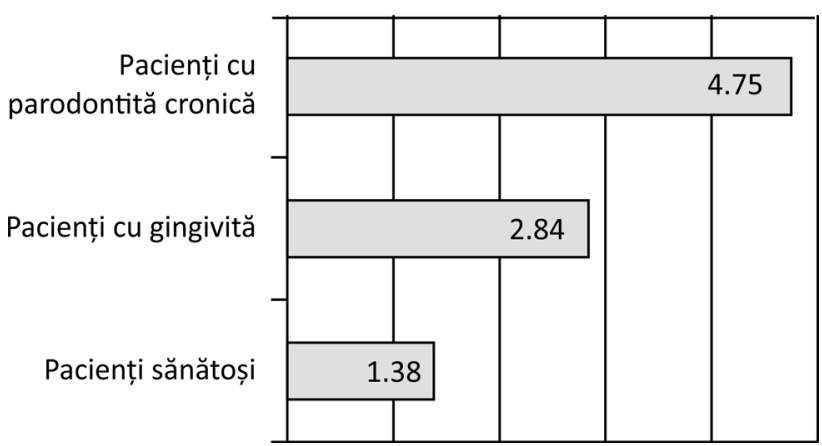

FIGURA 1. Adâncimea medie de sondare

CAL (edie \pm SD mm)

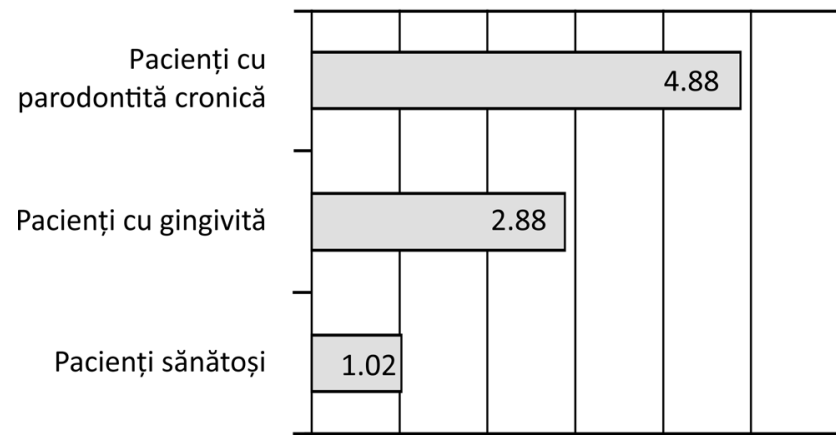

FIGURA 2. Pierderea medie de ataşament

Fumatul a fost asociat cu o rată crescută de formarea a plăcii bacteriene (Fig. 3), dar cu o sângerare gingivală redusă (Fig. 4) chiar şi la cei ce prezentau parodontită cronică.

Diferenţa dintre răspunsurile la sângerare a fost în general atribuită proprietăţilor vasoconstrictive ale nicotinei.
PI (v 1. medie + SD mm)

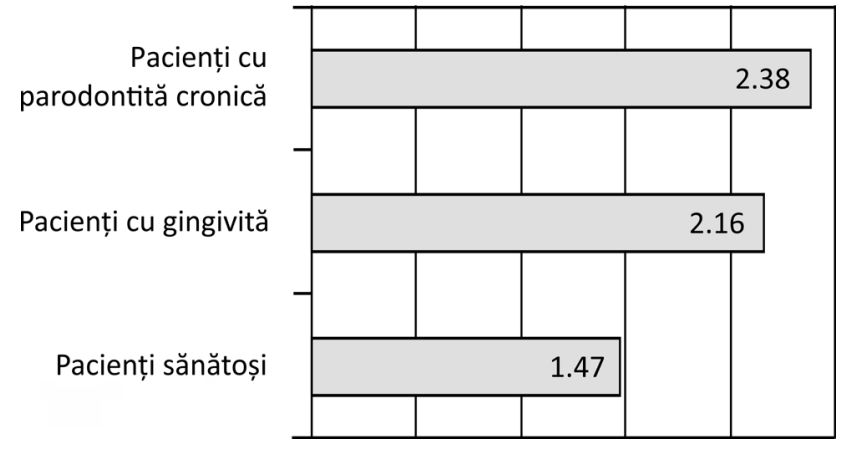

FIGURA 3. Valoarea medie a indicelui de placă

GI (v 1. medie \pm SD mm)

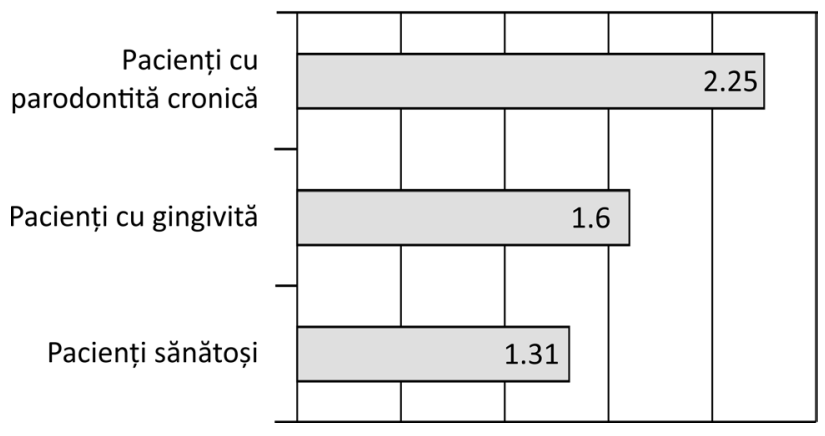

FIGURA 4. Valoarea medie a indicelui de sângerare gingivală

Din punct de vedere al evaluării microbiologice (Tabelul 1) s-au constatat următoarele: unele specii bacteriene au fost mai puţin răspândite în rândul fumătorilor, aşa cum s-a observat la Aggregatibacter actinomycetemcomitans, Fusobacterium nucleatum, Eubacterium nodatum, Capnocytophaga gingivalis.

Peptostreptococcus micros, Porphyromonas gingivalis, Prevotella intermedia, Treponema denticola şi Tannerella forsythia au fost prezente la toţi fumătorii, în special la cei cu cu parodontită cronică.

Ajustarea OR (ORadj) a fost adaptată pentru interpretarea rezultatelor, iar o valoare $p \leq 0,05 a$ fost considerată semnificativă din punct de vedere statistic deoarece SPSS nu a putut calcula OR pentru bacterii dacă prevalenţa a fost de $100 \%$ sau $0 \%$ in oricare din grupurile comparate.

Din punct de vedere al determinării CRP, au fost urmărite valorile în funcţie de tipul afecţiunii (Fig. 5), sex (Fig. 6), şi consumul de tutun zilnic (Fig. 7). CRP este un "trigger" proinflamator care stimulează producţia monocitară de IL-1, IL-6 şi TNF- $\alpha$, aceştia fiind şi principalii markeri de inflamaţie din boala parodontală. Deşi principala sursa de CRP este ficatul, date recente indică faptul că ţesutul ar- 
TABELUL 1. Evaluarea microbiologică la nivelul lotului studiat

\begin{tabular}{|l|c|c|c|c|}
\hline Specia bacteriană & Valoarea brută OR (95\% CI) & $\mathbf{P}$ & Valoarea ajustată OR (95\% CI) & $\mathbf{P}$-value \\
\hline Aggregatibacter actinomycetemcomitans & $0,57(0,2-2,1)$ & 0,40 & $0,76(0,1-4,1)$ & 0,74 \\
\hline Capnocytophaga gingivalis & $0,57(0,1-2,4)$ & 0,44 & $0,32(0,1-2,4)$ & 0,26 \\
\hline Eubacterium nodatum & - & - & - & - \\
\hline Fusobacterium nucleatum & $0,36(0,1-1,2)$ & 0,09 & $0,57(0,1-2,7)$ & 0,48 \\
\hline Peptostreptococcus micros & $2,20(0,6-9,2)$ & 0,28 & $3,22(0,2-48,8)$ & 0,40 \\
\hline Porphyromonas gingivalis & $1,26(0,4-4,0)$ & 0,70 & $4,37(0,7-26,5)$ & 0,11 \\
\hline Prevotella intermedia & $1,40(0,5-4,4)$ & 0,56 & $3,95(0,6-24,1)$ & 0,14 \\
\hline Tannerella forsythia & $1,00(0,2-6,1)$ & 1,00 & $2,68(0,2-29,9)$ & 0,42 \\
\hline Treponema denticola & $2,50(0,7-9,1)$ & 0,17 & $1,87(0,3-12,4)$ & 0,51 \\
\hline
\end{tabular}

terial poate produce atât CRP, cât şi proteine aparţinând sistemului complementului. Nivelul CRP poate înregistra creşteri foarte mari (de 100 ori sau chiar mai mult) după traumatisme severe, infecţii bacteriene, inflamaţii, intervenţii chirurgicale sau proliferări neoplazice.

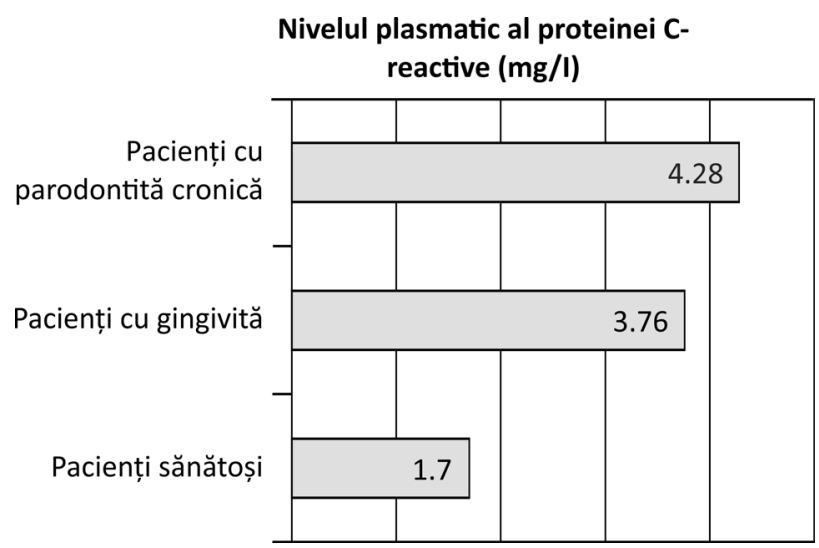

FIGURA 5. Valoarea medie a CRP în funcție de tipul afecțiunii

Nivelul plasmatic al proteinei Creactive $(\mathrm{mg} / \mathrm{l})$

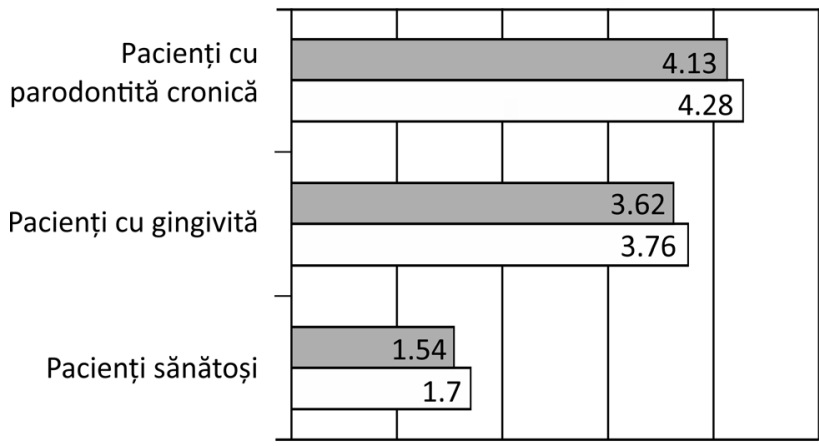

Femei

$\square$ Bărbați

FIGURA 6. Valoarea medie a CRP în funcție de de sex
Nivelul plasmatic al proteinei Creactive $(\mathrm{mg} / \mathrm{l})$

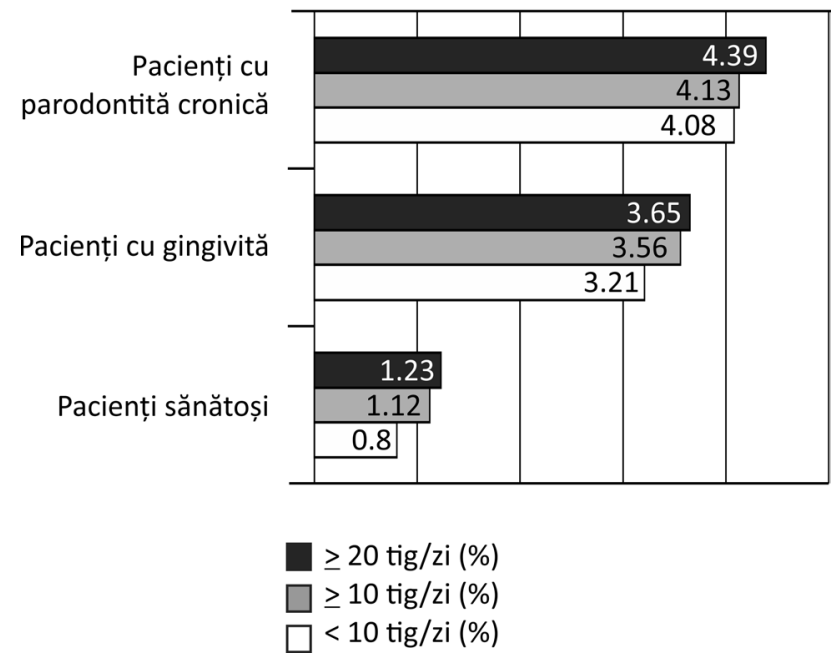

FIGURA 7. Valoarea medie a CRP în funcție de consumul de tutun

Fără a prezenta diferenţe semnificative, se poate observa faptul că fumatul unui număr crescut de ţigări pe zi produce creşteri ale nivelului proteinei C reactive. În urma prezentării rezultatelor precedente se poate deduce faptul că efectul clinic al fumatului se datoreaza utilizarii îndelungate a tutunului, deoarece rezultatele studiilor clinice ale efectelor imediate ale fumatului asupra circulaţiei gingivale nu susţin o acţiune vasoconstrictivă, sau atunci când este remarcată are o durată scurtă şi o intensitate redusă. Pare probabil că interferenţa fumatului cu capacitatea de răspuns inflamator a parodonţiului nu este datorată numai acţiunii vasoconstrictoare a nicotinei, ci e un rezultat al unei influenţe mai profunde asupra dinamicii vasculare şi metabolismului celular.

Influenţa sexului (masculin sau feminin) s-a dovedit a fi semnificativ diferită în grupuri. Acest lucru a fost atribuit în principal faptului că prevalenţa fumatului este mult mai mare la bărbaţi comparativ 
cu femeile. Argumentele pentru sunt observaţiile recente sugerând asocierea dintre fumat şi nivele crescute de proteină C reactivă.Acestea sugerează că nu numai reacţiile celulelor inflamaţiei dar şi alte funcţii celulare, ca de exemplu cele regenerative sunt influenţate de fumat. Astfel, fumatul asociat cu un răspuns inflamator inadecvat poate fi însoţit de o capacitate parodontală regenerativă inadecvată. Pe baza observaţiilor, putem deduce că fumatul ar putea determina schimbări în ecosistemele orale şi gingivale, ceea ce face ca mediul să fie mai favorabil pentru o creştere a anumitor specii bacteriene, iar pentru altele aceste schimbări fac ca mediul să fie mai puţin favorabil pentru creştere.Efectul fumatului asupra prevalenţei speciilor bacteriene a arătat că nu s-au putut determina modificări ale serotipului induse în principal de fumat.

\section{CONCLUZII}

Rezultatele studiului realizat confirmă faptul că fumatul are un efect de mascare a fenomenelor inflamatorii de la nivelul parodonţiului prin reduce- rea răspunsului hemoragic parodontal. De asemenea, fumatul afectează profilul bacterian subgingival şi este responsabil pentru scăderea numărului bacteriilor benefice şi creşterea bacteriilor parodontopatogene. Efectul fumatului se raportează la numărul de pachete de ţigări fumate pe zi, numărul de ani de fumat. Începerea fumatului devreme, chiar dacă numărul de ţigări este scăzut, va creşte riscul dezvoltării de boală parodontală mai târziu în viaţă. Fumatul se asociază cu o severitate crescută a pierderii de ataşament şi de os la vârste relativ tinere comparativ cu ne-fumătorii cu nivele de placă similare. Studii multi-transversale şi longitudinale privind asocierea dintre fumat şi boala parodontală au arătat că mărimea pungii parodontale, pierderea ataşamentului şi pierderea osoasă alveolară sunt mai prevalente la fumători decât la nefumătorii. Absenţa unei educaţii de conştientizare a riscurilor pe care le are fumatul de timpuriu din lipsa resurselor de informare îşi pune amprenta pe dezvoltarea armonioasă cât şi menţinerea unei sănătăţi orale prin resurse fiziologice.

\section{$\overline{\text { BIBLIOGRAFIE }}$}

1. Newman Michael $\mathrm{G}$ et al. Carranza's Clinical Periodontology. Elsevier Saunders, 2015.

2. Mârţu Slivia, Constanţa Mocanu. Parodontologie clinică. Editură Apollonia lasi, 2009.

3. Dumitriu Horia Traian. Tratat de parodontologie. Editura Viaţa Medicală Românească, 2015.

4. Zia A et al. Necrotizing Periodontitis in a Heavy Smoker and Tobacco Chewer - A Case Report. Advances in Pediatrics., U.S. National Library of Medicine, Dec. 2015, www.ncbi.nIm.nih.gov/ pubmed/26684494

5. Walsh PM, JB Epstein. The Oral Effects of Smokeless Tobacco. Advances in Pediatrics., U.S. National Library of Medicine, Jan. 2000, www.ncbi.nlm.nih.gov/pubmed/10680329.

6. Javed $\mathrm{F}$ et al. Association between Environmental Tobacco Smoke and Periodontal Disease: a Systematic Review. Advances in Pediatrics., U.S. National Library of Medicine, Aug. 2014, www.ncbi. nlm.nih.gov/pubmed/24926917.

7. Laxman VK, S Annaji. Tobacco Use and Its Effects on the Periodontium and Periodontal Therapy. Advances in Pediatrics. U.S. National Library of Medicine, 1 Nov. 2008, www.ncbi.nlm.nih.gov/ pubmed/18997922.

8. Johnson GK, M Hill. Cigarette Smoking and the Periodontal Patient. Advances in Pediatrics. U.S. National Library of Medicine, Feb. 2004, www.ncbi.nlm.nih.gov/pubmed/15068107.

9. Dumitriu Horia Traian. Tratat de parodontologie. Editura Viaţa Medicală Românească, 2015 